\title{
China and the Global Terms of Trade
}

\section{Raphael Kaplinsky}

\section{Working with the general and the particular}

The terms of trade have dominated development thinking since the early 1950s when Singer and Prebisch produced analyses of price trends, which suggested that there was a secular trend towards a fall in the commodities-manufactures terms of trade (Prebisch 1950; Singer 1950). The Singer-Prebisch hypothesis was more complex than is often acknowledged, for it not only took into account the income and price elasticities of demand for different products, but also the role played by labour markets in price determination (Kaplinsky 2005a). ${ }^{1}$ It resulted in a widespread commitment to industrialisation, premised on the expectation that the relative price of manufactures would continue to rise, and that of commodities to fall.

The estimation of the terms of trade is bedevilled by two major problems. First, it depends on the degree of aggregation which is involved. At the highest level of aggregation, "manufactures" and "commodities" are each categories which hide very significant variations. Manufactures, for example, includes purpose-manufactured 'complex production systems' (Acha et al. 2004), such as aerospace products which are based on cost-plus pricing, and very simple manufactured products (such as nuts and bolts) which are sold into very competitive markets. Similarly, "commodities" includes both precious materials such as diamonds and undifferentiated commodities such as robusta coffee. A second problem with the terms of trade discussion is that it is often undifferentiated by country. The terms of trade of a particular economy cannot be read off from the "average" terms of trade since it will have an individual pattern of trade, some of which may be subject to preferential pricing regimes, and this in turn depends on the direction of trade (e.g. there are at least three "prices" for sugar in different global markets).

Great care therefore has to be taken in deriving specific policy responses from generalised trends in prices. Nevertheless, generalised trends in prices do provide pointers to researchers for more detailed enquiry which might inform effective policymaking. This article addresses a general issue: what sorts of impact is the rise of the Asian Driver economies in general, and China in particular, having on global prices? The speed and recent nature of the rise of the Asian Drivers economies means that this impact is still uncertain; we also do not know if it will be sustained over time. Nevertheless, it will be argued below that the nature of the "price disturbances" which appear to be arising as a result of the size and rapid growth of China and India, is such that it is deserving of considerable further research, and careful attention by policy-makers. What follows, therefore, is a discussion which should be seen more as a pointer to further detailed research enquiry than as an input into detailed policy prescription.

Although this discussion focuses on the Chinese economy, by 2030 or sooner, it is likely that India will have become the world's third largest economy. This, too, could have a major impact on relative prices, particularly if its trade structure is similar to that of China, thus reinforcing the China-induced changes in global supply and demand.

\section{Why is China important?}

As we can see from Table 1, China's growth rate over the past two decades has been significantly more rapid than any of the various groupings of countries by income (and similarly by region, although we have chosen to use income-groupings as the comparator). Using purchasing power parity (PPP) constant prices, per capita incomes in China grew

IDS Bulletin Vol 37 No 1 January 2006 C Institute of Development Studies 
IDS Bulletin 37.1 Asian Drivers: Opportunities and Threats

Table 1: Relative growth rates, GDP per capita, 1985 PPP \$

\begin{tabular}{llll}
\hline & $\mathbf{1 9 8 0}$ & $\mathbf{1 9 9 0 s}$ & $\mathbf{1 9 9 7 - 2 0 0 2}$ \\
\hline Low income & 2.4 & 2.3 & 2.7 \\
Lower-middle-income & 2.5 & 2.3 & 4.3 \\
Middle income & 1.8 & 2.2 & 3.5 \\
Upper-middle-income & $? 0.8$ & 1.7 & 0.1 \\
High income & 2.4 & 1.8 & 1.7 \\
World & 1.6 & 1.5 & 2.0 \\
China & 8.3 & 9.3 & 6.7 \\
\hline
\end{tabular}

Source: World Bank, World Development Indicators (2004).

at an average rate of more than 8 per cent during the 1980s and more than 9 per cent during the 1990s. This far exceeded growth rates in any of the country income groupings.

This growth was increasingly outward-oriented. Before China's outward thrust (beginning around 1979), its trade-gross domestic product (GDP) ratio was less than 10 per cent, compared with a global average of almost 30 per cent. By 2002, its tradeGDP ratio had risen to 55 per cent, exceeding the global average of 47 per cent (Figure 1).

While the growth rate of China's exports has been no greater than that of the previous generation of Asian outward-oriented economies such as Japan and Korea from their point of trade expansion (Figure 2), it is the sheer size of China's economy which threatens to disequilibrate past patterns of price formation. This is reflected in China's growing share of manufactured imports into the US, the EU and Japan (Table 2). Between 1980 and 2002, its share of total manufactured imports (including many products which China does not produce or export in significant numbers) rose from virtually nothing to 14 per cent in the US. In the buyer-driven consumer products sectors, which have not been subject to major import quotas, its share of total imports has grown dramatically, particularly in the case of Japan and the US. In footwear, and toys and games where its presence has not been hindered by import quotas, it now accounts for more than twothirds of all imports into both the US and Japan and for two-thirds of imports of travel goods into the US. The pace of its growing presence in the clothing and textile sectors has hitherto been constrained by import quotas, but these quotas were removed in January 2005, with a consequent increase in market share

Figure 1: Trade as a proportion of GDP (\%), 1970-2002

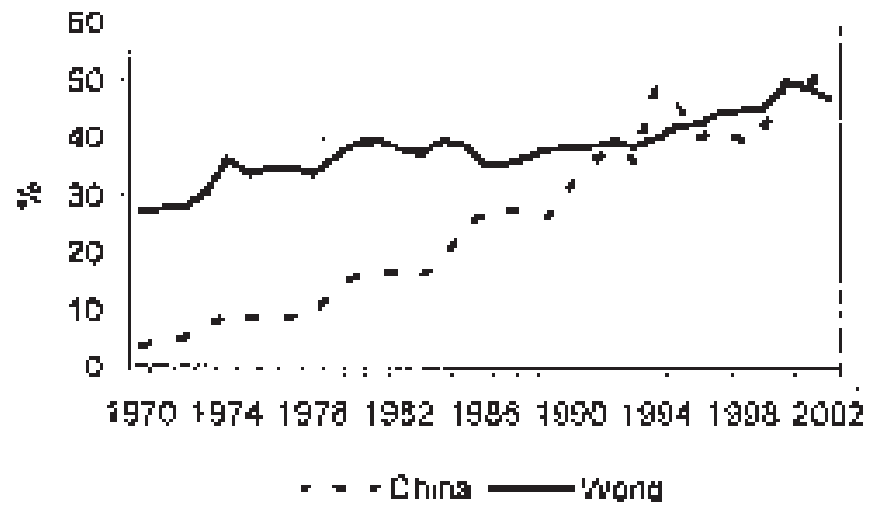

Source: Calculated from World Bank, World Development Indicators (2004). 
Figure 2: Growth path of exports from point of export-surge: Japan (1960-2003), Korea (1963-2003) and China (1979-2003)

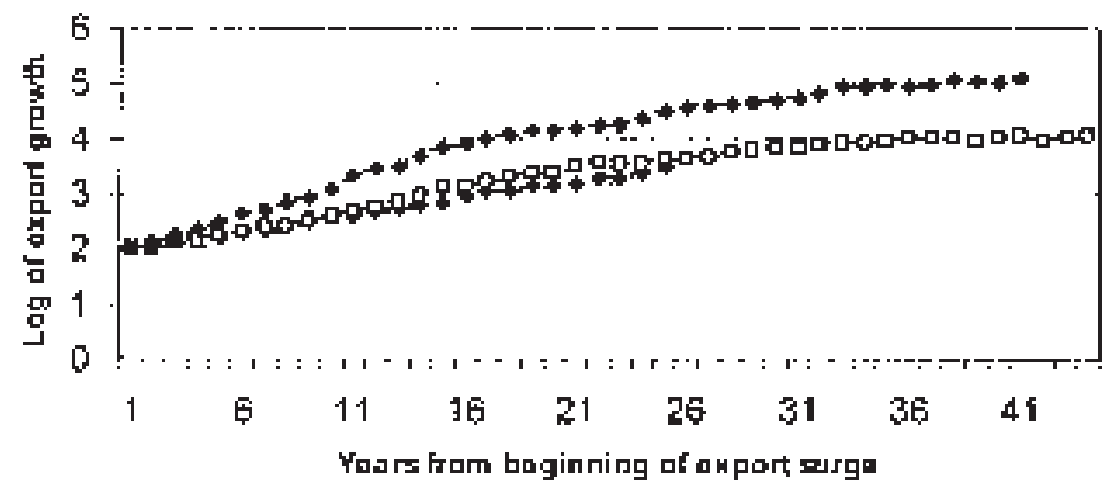

Calculated from World Bank, World Development Indicators (2004).

(see Morris and McCormick et al. in this IDS Bulletin). For example, following quota removal, China's share of EU clothing imports rose between the first quarters of 2004 and 2005 from 7 to 17 per cent for T-shirts, from 6 to 38 per cent for pullovers, from 6 to 35 per cent for men's trousers and from 10 to 45 per cent for linen fabrics (data supplied by Nathan Associates).

Another indication of the impact of China on global markets can be seen in the evolution of shipping freight rates (Figure 3). China's demand for imports and growth in exports has been so great as to lead to a shortage of global shipping capacity, manifesting itself in 2001. For both iron ore and grain, freight rates reached levels which were more than double the previous highs in 1973 and 1995 , respectively (although these rates are not pricedeflated). The cause? ... As a major ship-chandler observed: 'Chinese iron ore, steel and soybean demand was unquestionably the main reason ocean freight rates for dry bulk commodities hit all time highs earlier this year'. ${ }^{2}$

\section{China's trade and global prices}

At the same time that China's rapid growth and trade expansion have been proceeding, there have been signs of changing trends in global prices. In some cases, we can observe a trend of falling prices, in other cases of rising prices.

Table 2: Share of imports from China - EU, Japan and the US, 1995 and 2002

\begin{tabular}{|c|c|c|c|c|c|c|}
\hline & \multicolumn{2}{|c|}{ EU } & \multicolumn{2}{|c|}{ Japan } & \multicolumn{2}{|c|}{ US } \\
\hline & 1995 & 2002 & 1995 & 2002 & 1995 & 2002 \\
\hline All manufactures & 2.2 & 4.0 & 5.3 & 6.8 & 7.6 & 13.8 \\
\hline Textiles & 2.5 & 4.6 & 31.3 & 47.5 & 11.6 & 15.8 \\
\hline Clothing & 7.9 & 11.5 & 56.6 & 78.1 & 14.9 & 15.1 \\
\hline Other consumer products & 6.4 & 9.5 & 19.7 & 31.6 & 25.5 & 36.5 \\
\hline Footwear & 6.7 & 9.7 & 47.3 & 67.4 & 52.3 & 68.2 \\
\hline Travel goods & 40.4 & 45.1 & 32.9 & 45.2 & 47.4 & 64.2 \\
\hline Toys and games & 26.0 & 35.8 & 26.4 & 63.5 & 48.4 & 66.6 \\
\hline Furniture & 7.0 & 6.2 & & & 11.2 & 34 \\
\hline
\end{tabular}

Source: Kaplinsky (2005b). 
Figure 3: Shipping freight rates, 1973-2003

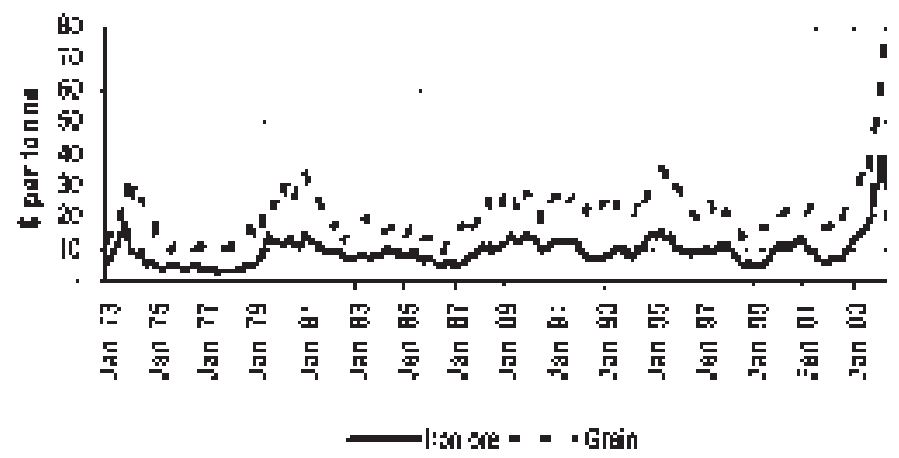

Source: Kaplinsky (2005b).

\subsection{Declining prices of manufactures}

Much of the second half of the twentieth century was a period of inflation in the global economy. Prices of most commodities rose, although the price rise was faster for manufactures than for primary products. By the 1990s, most economies had begun to get on top of high rates of inflation and for the Organisation for Economic Co-operation and Development (OECD) economies as a whole, the rate of inflation at the turn of the millennium was less than 3 per cent. What followed was a period of price deflation in manufactures, beginning with a slowdown in the rate of inflation in the late 1980s, and then after 1998, in absolute nominal prices (Figure 4).

How does China's trade expansion relate to these falling prices? The terms of trade literature is almost entirely based on the use of aggregated data, mostly using Standard International Trade Classification (SITC) three- and very occasionally SITC four-digit classifications. As we observed above, this is not adequate for a detailed examination of prices. The HS trade classification system introduced in the late 1980s has a much finer degree of disaggregation and provides greater scope for the detailed tracking of product prices. At the eight-digit level there are 10,000 different HS product categories. The EU provides a unique data-set on international trade and is large enough to use as a surrogate for the behaviour of global product prices. (However, as with all HS trade data, this data-set only stretches back to 1988.)

Figure 4: World manufacturing export price, 1986-2000

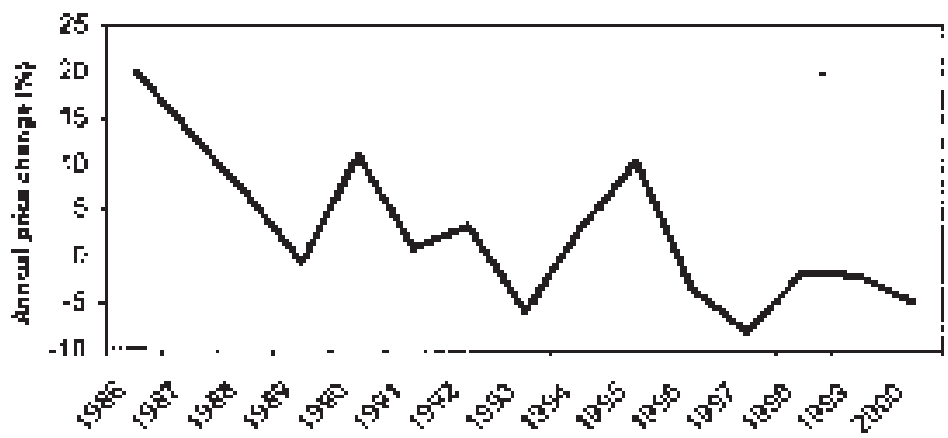

Source: IMF, World Economic Outlook Database, September (2003). 
Figure 5: Percentage of sectors with negative price trends, 1988/9-2000/01 by country groupings

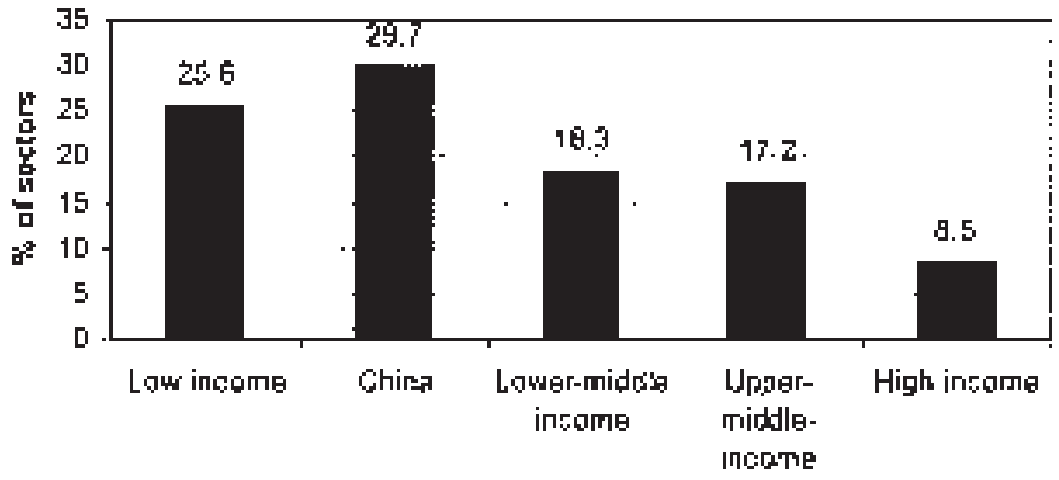

Source: Kaplinsky (2005b).

Figure 5 analyses changes in the global prices of manufactures which are of major concern to developing country exporters. It focuses on the major product-groupings (classified at the eightdigit level) imported into the EU where developing country exporters were prominent. It reports the proportion of the sectors for which the unit price of imports from different income groups (and China) fell between 1988 and 2001. It can be seen from this that in almost one-third of these sectors, the price of Chinese-origin products fell. In the case of products emanating from low-income economies, the proportion of product group in which unit prices fell was around one-quarter. As a general rule, the higher the per capita income group of the exporter, the less likely unit prices fall. Thus, within a significant number of product groups, the prices of products exported into the EU by China and low-income economies was more likely to decline than the prices of the same products-groupings sourced from other high-income economies.

We draw two conclusions from this price analysis. First, the greater China's participation in global product markets, the more likely prices will fall. And, second, this seems to have a disproportionate impact on the low-income country group who faces intense competition from Chinese producers.

\subsection{Rising prices of hard commodities'}

By definition, manufactures involve the transformation of inputs into outputs. In the case of automobiles, for example, more than 5,000 components are involved, and each of these in turn requires the input of a variety of raw- and semi-processed materials. The advance of global value chains over the last two decades of the twentieth century resulted in a significant increase in global trade in components and hence in a growth of import intensity in export production in almost every country. For example, in the case of China, the proportion of export revenue which reflected direct imports into production processes rose from 8 to 12 per cent between 1980 and 1998, and in the case of direct and indirect imports (that is, taking account of the imports going into the production of domestically sourced inputs), it rose from 15 to 23 per cent in the same period (Martin and Manole 2003).

Consequently, with rapidly growing production destined for both the domestic and export market, it is not surprising that China has become a very large market for the exports of other countries. In many cases, it has imported manufactured products, particularly capital goods from Japan. In addition, Chinese exports of products such as consumer electronics, have involved the assembly of components sourced from the East Asian region. ${ }^{3}$ However, from the perspective of developing economies, particularly those outside of the East Asia region (see Evans et al. in this IDS Bulletin), it is China's sourcing of "hard" and semi-processed commodities which represent a particularly significant impact on prices in the global economy.

Focusing on basic metals as an example, China's demand for imports has been fuelled by three factors. The first has been the rapid growth of 


\section{Figure 6: Actual and projected global share of China's consumption of base metals, 1950-2010}

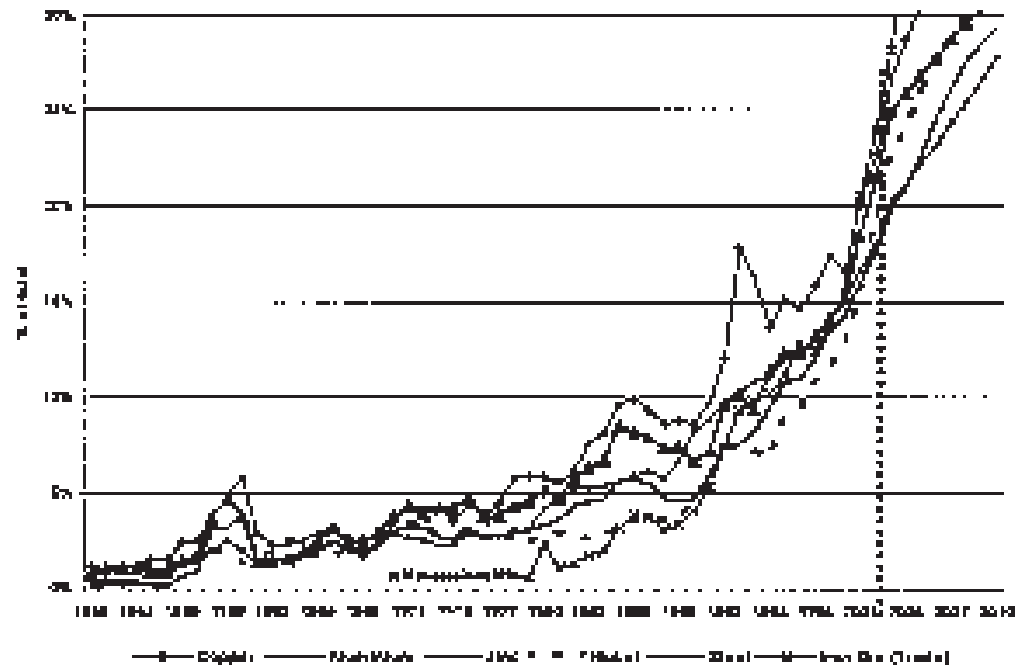

Source: Macquarie Research Metals and Mining, personal communication (2004).

domestic demand for household consumer goods and autos (where production has grown at a dramatic pace). Second, there has been very substantial investment in infrastructure, both in the public and private sector, and this has been particularly metals-intensive. And, third, many of China's exports have been of metal-based products. Consequently, China's share of global demand for the main base metals (aluminium, copper, iron ore, nickel, steel and zinc) grew from 17 per cent of global demand in 1993 to 20-25 per cent in 2003. In the case of steel, its share has grown from less than 10 per cent in 1990 to more than 25 per cent in 2003, equivalent to three times that of Japan, and more than either the EU or the US (around 20 per cent each). Between 2000 and 2003, China's share of the increase in global demand for aluminium, steel, nickel and copper was 76 per cent, 95 per cent, 99 per cent and 100 per cent, respectively. As Figure 6 shows, its projected utilisation of these basic metals is likely to grow even further in the future, in part because of its relatively low per capita consumption of these materials (Table 3 ) - bear in mind that China accounts for more than 20 per cent of global population and it is inevitable that as incomes grow and the minerals-intensity of consumption grows as it has in other countries, this will continue to lead to rising demand for imported materials.

This thirst for mineral imports is also reflected in the food sector, where falling land availability (a consequence of rising industrialisation) and stagnant agricultural productivity have led to rising food imports. In the first half of 2004, China had a trade deficit on foodstuffs of US $\$ 3.7 \mathrm{bn}$, including imports of $4.1 \mathrm{~m}$ tonnes of foodgrains. It is predicted that this deficit will soar in the future; in the case of foodgrains, to around $40 \mathrm{~m}$ tonnes by 2007 (Financial Times, 23 August 2004).

This expansion in Chinese commodity imports has been closely reflected in the global prices of many hard commodities. For example: ${ }^{4}$

- Between 2002 and 2004, the price of hot-rolled coil steel rose from around US\$140/tonne to more than US $\$ 500 /$ tonne, significantly higher than the previous postwar peak of US $\$ 400 /$ tonne in 1994.

- Prices of spot steam coal (cif Rotterdam) leapt from US\$27/tonne to US\$82/tonne between 2002 and 2004, higher than the previous postwar peak of 1981. Hard-coking coal prices jumped from US\$50/tonne to more than US\$100/tonne in the same period, a postwar high. 
Table 3: The scope for China's increased consumption of basic metals, 1955-2003

kg per capita

GDP per capita (US\$ 1995)

\begin{tabular}{cllll}
\hline & Aluminium & Copper & Steel & \\
\hline $\begin{array}{c}\text { Japan } \\
1955\end{array}$ & 0.6 & 1.2 & & \\
1975 & 10.5 & 7.4 & 80 & 5559 \\
Korea & & & 599 & 21,869 \\
1975 & 1.0 & 1.3 & 84 & 2891 \\
1995 & 15.0 & 8.1 & 827 & 10,841 \\
China & & & & \\
1990 & 0.7 & 0.6 & 59 & 342 \\
1999 & 2.3 & 1.2 & 108 & 756 \\
2002 & 3.3 & 2.0 & 160 & 933 \\
2003 & 4.0 & 2.4 & 200 & 1103 \\
\hline
\end{tabular}

Source: Macquarie Metals and Mining, personal communication, 2004.

- Between 2001 and 2004, copper prices more than doubled from around 63cts/lb to US $\$ 1.40 / \mathrm{lb}$, although in this case they were still lower than the previous postwar peak of US $\$ 1.55 / \mathrm{b}$ in 1989 .

These are undeflated prices and represent a price spur which has been very recent (that is, since 2000). However, they reflect the data presented in Figure 6 above on China's augmentation of global demand in hard commodities. Will they endure? The data in Table 3, allied to China's continued rapid growth, suggests that this is not a short-term blip in commodity prices.

\section{Implications for the terms of trade}

How might the data presented in Section 3 above be reflected in the terms of trade, that is the prices of manufactures relative to the prices of commodities? First, the data challenges the view that commodity prices are on a downward trend. As we have seen, the price of many of the "hard commodities", which have previously been in longterm decline, appear to have risen in the early 2000s. In many sectors, there are supply constraints, and the gestation period for new investments to come on stream often exceeds five years. Moreover, it is not inevitable that the prices of all primary "soft commodities" will fall. There are opportunities for value accretion in these commodities which reflect the same processes of Schumpeterian rents, which Singer and Prebisch argued were unique to manufactures in the 1950s. There is an increasing number of niche-market speciality commodities: organic and fair-traded products, shade-grown coffee, exotic fruits and vegetables, and so on, each of which earns a rent in increasingly differentiated product markets. It is significant here that the most accurate indicator of per capita incomes of shoppers in the UK is the share of (predominantly imported) fresh fruit and vegetables in their shopping trolleys.

At the same time, the data in Section 3 above challenges the assertion in the early Prebisch-Singer thesis, questioned in Singer's revisiting of the terms of trade debate in the early 1970s and early 1990s (Singer 1971; Sarkar and Singer 1991), that manufactured prices would continue to rise. There is a significant category of manufactures, particularly those in which China participates, in which prices appear to be falling. Figure 5 above shows the results of a detailed inquiry at the eight-digit level, but there is anecdotal evidence available to virtually every reader of the sometimes astonishing fall in product prices. This author recently purchased an electronic watch (having the identical electronic movements as a US $\$ 100$ watch) plus ten videotapes (all made in China) for a retail price of around $£ 6.99$. Referring back to China's growing share of T-shirts, pullovers and men's trousers noted earlier, in the same time period (first quarter of 2004 to first 
Table 4: Employment in formal sector manufacturing, 1995-2002

\begin{tabular}{|c|c|c|c|c|c|c|c|c|}
\hline & \multicolumn{4}{|c|}{ Employment ('000) } & \multicolumn{4}{|c|}{ Index of employment $(1995=100)$} \\
\hline & OECD $14^{*}$ & China & India & Brazil & OECD $14^{*}$ & China & India & Brazi \\
\hline 1995 & 85,623 & 98,030 & 6,500 & 9,438 & 100 & 100 & 100 & 100 \\
\hline 1996 & 84,508 & 97,360 & 6,800 & 8,739 & 99 & 99 & 105 & 93 \\
\hline 1997 & 83,003 & 96,120 & 6,900 & 8,381 & 97 & 98 & 106 & 89 \\
\hline 1998 & 81,728 & 83,190 & 6,800 & 7,882 & 95 & 85 & 105 & 84 \\
\hline 1999 & 81,266 & 81,090 & 6,700 & 7,420 & 95 & 83 & 103 & 79 \\
\hline 2000 & 81,486 & 80,430 & 6,600 & 7,478 & 95 & 82 & 102 & 79 \\
\hline 2001 & 80,535 & 80,830 & 6,400 & 7,565 & 94 & 82 & 98 & 80 \\
\hline 2002 & 78,761 & 83,080 & 6,500 & 7,556 & 92 & 85 & 100 & 80 \\
\hline
\end{tabular}

"US, Canada, Germany, UK, Japan, Russia, Italy, France, Taiwan, Korea, Spain, Netherlands, Austria, Sweden. Source: Calculated from Carson (2003).

quarter of 2005), the respective average prices of these commodities fell by 26, 47 and 16 per cent.

How might global prices evolve in the short- to medium-term future? Here we can distinguish between the demand and the supply sides of these changing conditions affecting global prices. On the demand side, there is no reason to doubt that the scope for consumption in general, and niche-based consumption in particular, will continue to grow. Indeed, as global incomes rise, including in consumption-conscious China, the search for positional goods is likely to strengthen the demand for differentiated products, including differentiated "soft commodities". Similarly, although there are many who doubt whether China can sustain an annual growth rate of more than 9 per cent for many decades into the future, there is widespread agreement that it will continue to grow rapidly, and at a faster rate than the global economy as a whole. Given that China accounts for almost one-fifth of the global population, this suggests a world of robust demand. Moreover, lurking around the corner is the spectre of India, likely to have a population larger than China by 2030, and currently also growing at more than 6 per cent a year since the late 1990s.

If demand is likely to be robust, what of supply? Will China begin to experience capacity constraints which will diminish its potential for forcing global product prices in manufactures down? One sign that this might be the case is the shortage of labour in the coastal region and in Beijing in the summer of 2004. However, this labour shortage was an aberration, associated with the concentration of manufacturing production in the eastern coastal regions and the high cost of living encountered by migrant labour. China has, and continues to have a very large reserve army of labour in the interior, and firms locating away from the coast pay much lower wages. The Japanese managing director of a Chinese subsidiary observed - 'If we run out of people we just go deeper into China' (Roberts and Kynge 2003).

Table 4 shows that in the largest 14 OECD economies - the economies with high wages threatened by imports from low-wage economies - employment in formal-sector manufacturing fell by 8 per cent between 1995 and 2002. But what is perhaps even more surprising is that contrary to expectations, there was an even more significant fall in employment in China (by 15 per cent), and by 20 per cent in the third largest developing country manufacturing sector (Brazil). The overall picture for these 17 largest manufacturing economies was a decline in total employment in formal sector manufacturing from $200 \mathrm{~m}$ to $176 \mathrm{~m}$, a fall of 12 per cent in seven years.

The experience of China is particularly surprising since, as we saw in Table 1, it has been such a successfully growing economy. It is also a particularly important economy due to its size, with a formal sector employed labour force larger than that in the combined 14 largest OECD economies. However, the rapid growth in employment during 
Figure 7: The global labour force (2002)

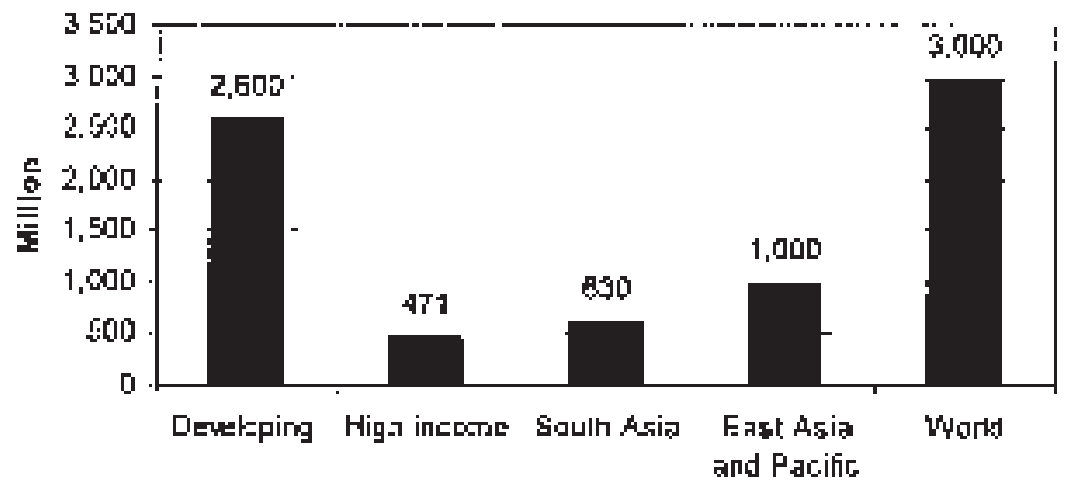

Source: World Bank, World Development Indicators (2004).

the first half of the 1970s gave way to a process of employment displacement during the 1990s, particularly in state-owned enterprises and township and village enterprises (TVEs). As China entered the global economy after the early 1980s, this labour displacement was particularly acute in manufacturing. But it is also evident in mining (Rawski 2003). Even these numbers underestimate the extent of real labour displacement in China, since many people in the state-owned and township and village enterprises remain on the books but are effectively unemployed. This is because there remains a residue of enterprises which continue to keep workers on their payroll (so that they can get access to social security services), even though there is no sense in which they are actually working productively ( $\mathrm{Gu}$ 2003). A variety of observers concur that there are something like 100-150 million people in China currently working at very low levels of productivity and who are waiting to be absorbed into the global economy. This surplus labour force is equivalent to more than one-quarter of the total labour force in all high-income economies. Yet, this labour surplus does not show up in Chinese labour statistics: 'The officially released low (formal) unemployment figures, however, do not reflect the severity of the actual high unemployment ... [which] ... takes place in urban China, not in the form of open unemployment, but rather in the form of lay-offs. Laid-off workers, according to an official definition, are those who loose [sic] their jobs as their employing units encounter economic difficulties, while still maintaining their nominal employment relationship with their employees' ( $G u$ 2003: 2). Rawski concludes that '[e]xpansion of formal employment during the 1990s is entirely attributable to increases in rural jobs ... [and] employment prospects deteriorated dramatically after 1995, with large numbers pushed out of the formal sector' (Rawski, 2003: 4-5). One of the consequences of this opening-up to the global economy, argues Rawski, is that the barriers to domestic migration have dropped sharply, so that up to $100 \mathrm{~m}$ people moved their place of residence during the 1990s.

This indicates that wages are unlikely to grow in China in the medium term, at least in the exportoriented manufacturing industries which have the capacity to move into the interior and be serviced by the mass of rural unemployed and underemployed. ${ }^{5}$ And, if and when they do, India sits on a labour force of $470 \mathrm{~m}$ (compared with the $770 \mathrm{~m}$ in China), and there is a plentiful supply of labour in Indonesia and other populated Asian economies (Figure 7). The medium-term prognosis for manufacturing prices, or at least for those manufactures which can be produced by lowincome economies such as China and India (and this includes a growing number of highertechnology sectors), is of continuing price pressures.

\section{The wider implications}

There are a number of wider implications which follow on from this preliminary analysis, affecting the research agenda, theory and policy. 
First, the data presented in the earlier sections of this article are essentially speculative. Although the analysis of manufacturing prices was undertaken at an unusually high level of disaggregation, there is further scope for the careful tracking of price trends of both manufactures and commodities (and indeed also of services) over time and at a level which allows for the capturing of the increasing differentiation of product markets. This then needs to feed into the relativity of prices between different types of products and, to be useful as a policy tool, to the trade-weighted terms of trade of individual economies. But detail is important in this analysis, particularly in the context of the growing differentiation of product markets.

Second, an association between the rising global presence of the Asian Driver economies in general, and China in particular, and trends in global prices has been noted. While this article has argued that this is a causal link, this may be only a weak causal link. Other factors, including the feeding through of higher energy prices, changing exchange rates and the determination of global demand and supply may be playing an equally important, if not more important role in determining price trends. Unravelling the contribution of these differing contributors to price formation is an important challenge for further research.

Third, assuming that these price changes are more than a temporary blip, they pose major challenges for development policy. To what extent should industry be given primacy over agriculture, or indeed services? Or is it rather a matter of different

\section{Notes}

1. One little-noted explanation for changing terms of trade in the Prebisch-Singer analysis was that prices were in large part determined by labour markets. In the industrialised countries, tight labour markets and powerful trades unions led to cost-plus pricing; in less developed economies, labour-surpluses led to labourpool determined wages and low prices. In those days, less developed countries exported commodities and industrialised economies exported manufactures, and in the absence of suitable databases for the price of different types of products, Prebisch-Singer used the commodities-manufactures terms of trade as a surrogate for country- and product-specific prices.

2. Tom Cutler, Clarksons, personal communication.

3. China's trade deficit with East Asia grew from US $\$ 4$ bn in 1990 to US\$40bn in 2002, and the region's share of China's merchandise imports grew from 55 to 62 per cent in the same period (Lall and Albaladejo 2004). types of industry (briefly, activities incorporating innovation rents) and different types of commodities and services? In this case, the policy challenge is one designed to encourage innovation generically, rather than a particular economic sector. If, so how can these "dynamic capabilities" (Teece et al. 1992) be endogenised and, as a particular development challenge, made accessible to poor producers?

Finally, to the geopolitics of the rise of the Asian Drivers. In previous eras of rapid growth, there has been close correspondence between price trends and geopolitical positioning. In the nineteenth century, the commodity hunger of industrialising Europe led not just to rising demand for commodities, but also to colonialism and imperialism. In the post-World War II era, some argued that the requirements of the US for industrial materials led to its growing imperialistic footprint during the 1960s (Magdoff 1969) and to its involvement in the Gulf Wars in the early 1990s and in 2003 (Rutledge 2005). If true, what lessons can be learned with regard to the growing resource hunger of the Asian Drivers? What will be the implications of China's growing trade and commercial links with African economies in the midst of civil war and/or with very poor human rights records? To what extent does this resource hunger explain the establishment of overseas aid programmes by both China and India? And how close is the connection between these changing price trends and the associated geopolitical repositioning of the Asian Drivers and other global and regional power?

4. All data from Macquarie Research.

5. This is not inconsistent with rising wages in the coastal regions associated with the production of higher technology products. China possesses such a large expanse and working-age population that it is able to work with a segmented labour market. High-tech industries with high wages, competing with products from high-income economies will be located on the coastal region; low-tech industries competing with low-wage economies will be located in the interior. 


\section{References}

Acha, V., Davies, A., Hobday M. and Salter, A., 2004, 'Exploring the capital goods economy: complex product systems in the UK', Industrial and Corporate Change, Vol 13 No 3: 505-29

Carson, J.G., 2003, US Weekly Employment Update, New York: Alliance Bernstein

Gu, E., 2003, 'Labour market insecurities in China', SES Papers 33, Geneva: International Labour Organization

IMF, 2003, World Economic Outlook Database, September

Kaplinsky, R., 2005a, Revisiting the Terms of Trade Revisited: What Difference Does China Make?, www.ids.ac.uk/ids/global/Asiandriversbackground papers.html (accessed September 2005)

Kaplinsky, R., 2005b, Globalization, Poverty and Inequality: Between a Rock and a Hard Place, Cambridge: Polity

Lall, S. and Albaladejo, M., 2004, 'China's competitive performance: a threat to East Asian manufactured exports?', World Development, Vol 32 No 9: 1441-66

Magdoff, H., 1969, The Age of Imperialism, New York: Monthly Review Press

Martin, M. and Manole, V., 2003, 'China's emergence as the workshop of the world', mimeo, Washington, D.C.: World Bank

Prebisch, R., 1950, 'The economic development of
Latin America and its principal problems', Economic Bulletin for Latin America 7, New York: United Nations

Rawski, T.G., 2003, 'Recent developments in China's labor economy', mimeo, Pittsburgh: Department of Economics, University of Pittsburgh

Roberts, D. and Kynge, J., 2003, 'How cheap labour, foreign investment and rapid industrialisation are creating a new workshop of the world', Financial Times, 4 February

Rutledge, I., 2005, Addicted to Oil: America's Relentless Drive for Energy Security, London: I.B. Taurus

Sarkar, P. and Singer, H.W., 1991, 'Manufactured exports of developing countries and their terms of trade', World Development, Vol 19 No 4: 333-40

Singer, H., 1971, 'The distribution of gains revisited', reprinted in A. Cairncross and M. Puri (eds), 1975, The Strategy of International Development, London: Macmillan

Singer, H.W., 1950, 'The distribution of gains between investing and borrowing countries', American Economic Review 15: 473-85

Teece, D., Pisano, G. and Shuen, A., 1992, Dynamic Capabilities and Strategic Management, Berkeley: University of Berkeley Press

World Bank, 2004, World Development Indicators, Washington, D.C.: World Bank 